Available online at GSC Online Press Directory

GSC Biological and Pharmaceutical Sciences

e-ISSN: 2581-3250, CODEN (USA): GBPSC2

Journal homepage: https://www.gsconlinepress.com/journals/gscbps

(REVIEW ARTICLE)

\title{
Improvement in sausage manufacturing process and potential use of selected aromatic plants as their bio preservatives in Benin
}

\author{
Gbaguidi Mauricette D. Dévi ${ }^{1}$, Degnon René Gnimabou ${ }^{1,}{ }^{*}$, Konfo Tétédé Rodrigue Christian ${ }^{1,2}$ Kpatinvoh \\ Brice ${ }^{1}$ and Baba-Moussa Farid ${ }^{3}$ \\ 1 University of Abomey-Calavi, Polytechnic School of Abomey-Calavi, Laboratory of Study and Research in Applied \\ Chemistry, 01 PO Box: 2009 Cotonou, Benin. \\ ${ }^{2}$ National University of Agriculture (UNA), Schools of Science and Techniques for Preservation and Processing of \\ Agricultural Products (ESTCTPA), Food and Bioresources and Human Nutrition Science and Technology Laboratory, PO \\ Box114, Sakété, Benin. \\ ${ }^{3}$ Laboratory of Microbiology and Food Technology, Faculty of Science and Technology / University of Abomey-Calavi, \\ ISBA-Cotonou, Benin.
}

Publication history: Received on 13 June 2020; revised on 21 June 2020; accepted on 23 June 2020

Article DOI: https://doi.org/10.30574/gscbps.2020.11.3.0180

\begin{abstract}
Sausages are among the most common processed meat products worldwide. These products have very high water activity and microbial load, which leads to a short shelf life. To improve their quality and increase their shelf life, the food industry uses several chemicals with harmful consequences on health. Recently, research in essential oils has received increased attention from both industrial and academic circles due to a growing interest in green consumerism and the need for alternative techniques to assure quality and safety of perishable foods. In this review, we have summarized studies dedicated to improving the quality and technology of sausage production. Particular emphasis was placed on essential oils.
\end{abstract}

Keywords: Sausage; Processing; Natural preservatives; Essential oils; Benin.

\section{Introduction}

For millennia, man's main concern was to find and preserve food. It was from the end of the 19th century that the production of cured meats began to industrialize. Nowadays, the production is mainly carried out by specialized industrial companies which reconcile the traditional aspect of cold cuts and the most recent scientific and technological advances. The processing of meats is essentially the result of the concern to obtain from fresh meats, products that can be preserved in order to spread their consumption over time. In addition, the profession, in order to respond to consumer demands, has extended its activity to the production of poultry cold cuts [1]. Sausages are products manufactured from fresh comminuted meats from different meat species, such as pork, beef, chicken, fish and buffalo [2]. Sausages like other cold meats provide the human body with proteins of good biological value, vitamins, minerals, lipids and energy [3].

Their richness in proteins and the nature of these make these products essential foods for a balanced food ration. However, due to their nutritional qualities, sausage and sausage are very favourable environments for contamination [4]. These microbial contaminations can, on the one hand, alter their marketable qualities (taste, smell, appearance, etc.) and, on the other hand, they cause two types of food-borne illness: food poisoning and Infectious diseases [5].

\footnotetext{
* Corresponding author: Degnon René Gnimabou
} 
Toxins are exceptionally heat-resistant proteins: it takes in vitro 3 hours at $100{ }^{\circ} \mathrm{C}$ and 10 to 40 minutes at $120{ }^{\circ} \mathrm{C}$ to destroy the toxin. They resist digestive enzymes and gastric acidity. The main toxin producing germs are: bacteria (Salmonella, Listeria, Yersinia, Campilobacter, Staphylococci, Clostridium, Jejuni, Escherichia), molds and viruses [6].

The antimicrobial and/or antioxidant preservatives currently employed in these products are chemicals, e.g. sulphur dioxide $\left(\mathrm{SO}_{2}\right)$, benzoates, sulphites, a-tocopherol, calcium chloride and citric acid as antimicrobial and colour preservative [7] and/or synthetic antioxidants such as butylated hydroxytoluene (BHT), butylated hydroxyanisole (BHA) and propyl gallate [8] (Kim, Cho, \& Han, 2013). However, at short or long-term, these synthetic chemical products could be very toxic, with risks of mutagenicity, chromosomal aberrations and cancer $[8,9,10]$, allergic reactions in sulphite hypersensitive consumers. Otherwise, symptoms such as asthma, urticaria, abdominal pains, nausea, diarrhoea, seizures and anaphylactic shock resulting in death have been recorded $[2,8]$.

Due to the resurgence of the harmful effects of these chemical substances on the human health, the use of essential oils generally recognized as safe (GRAS) as bio preservatives agents of food products could be a credible alternative [11, 12, $13,2,14,15,16$,$] . Indeed, essential oils possess antimicrobial activities and are without major effects on the$ environment and human health [10]. This article aims primarily to summarizing the research results on improvement of sausage processing, current trends in natural preservatives for sausage products and potential use of essential oil as their bio preservative [10].

\section{Definition and history of sausages}

\subsection{Definition}

A sausage is a charcuterie product mainly composed of minced meat mixed with other ingredients such as spices and condiments, the preparation is then placed in a gut, of intestinal or synthetic origin, in the form of a tube and closed at the ends. However, there are also meatless vegetarian sausages, made from soya cheese or vegetables for example. The length and the size of the sausage can vary according to the recipes, different cultures in the world being able to manufacture sausages according to their local methods and the tastes of its consumers [17].

\subsection{History of sausages}

Because sausage manufacturing has been practiced before recorded history, it is not certain how and when the first sausage was produced [18]. To date and to our knowledge, no scientific research published in a serious scientific journal has been interested in the history of sausage production. However, the word "sausage", however, is derived from saussiche (Old Norman French), salsıcia (Late Latin) or from salsus (Latin) which means "salted" [19-20]. According to an article published on the site [https://fr.wikipedia.org/wiki/Saucisse\#: :text=Histoire,et\%20Cic\%C3\%A9ron\%20dans\%20certains\%20r\%C3\%A9 cits Last accessed on 21/06/2020] and which does not do not cite its sources enough; the sausage would have been born 4,000 or 5,000 years ago. Homer already spoke of it in the Odyssey and Cicero in certain stories. It is likely that it was invented with a view to preserving or facilitating the transport of meat, as was its use in Antiquity, or simply from a principle of economy among butchers. Some Roman legions used the sausage principle to transport pre-divided meat. Often the envelope was thrown away and only the inside was kept, in order to prepare the famous "legionary rations" which then included the equivalent of one sausage per meal. It should be noted that the sausage in Rome was introduced from the ancient city of Lucanica. From this import came the export to certain places like North Africa where Gaul adopted it and used it according to the same principle. A Roman festival also existed for the sausage; Lupercales were celebrated by eating sausage at the time.

It is certain that at the same time the Chinese often used a principle similar to the European sausage, using goat and lamb meat. In the Middle Ages, quality sausage was produced, to which spices and spices were added, which were brought in from the East at great cost by the famous silk route. It is reported among other things that in the Byzantine Empire blood sausage was, for a time, prohibited, because of a problem of food poisoning, frequent at the time.

An Anglo-Saxon tradition dating from the Second World War means that the majority of sausages have a high level of starchy foods, up to $25 \%$, in order to compensate for the lack of meat of the time. The remaining practice is mainly used during cooking: while the meat contracts when cooked, the starchy food (flour, starch, etc.) expands by absorbing water and part of the fat, thus making it possible to do not distort the sausage. Although the process has been known since the Middle Ages (and used among others in Germany), it is from this event that modern tradition comes to us, because some industrial production of cheap foodstuffs could be established at that time. . 
Since the end of the 20th century, the sausage is often seen far from fine cuisine, although there is always a certain refinement in the world of sausage, but also because the majority of sausages have very high fat and salt levels. Today the sausage is often perceived as a recovery of edible meat waste, known as mechanically separated meat, filled with chemical preservatives [19].

\section{Sausage classification}

According to Rust [21] sausage production began with a simple process of salting and drying the meats which helped improve the shelf life of the sausages. Subsequently, aromas and spices were incorporated to improve the organoleptic quality of the product. The product was then stuffed in a container, namely the gastrointestinal tract of animals, to make the product more convenient to eat.

The manufacturing process may vary because seasoned meat is minced, stuffed in casings, and can be smoked, dried, fermented and heated. There is a large variety of sausages and the different variants are linked to the modification of the type of meat, the processing temperature, types of casings and the particle size of the casings [2, 18]. Table 1 shows the different types of sausages.

Table 1 Sausage classification

\begin{tabular}{|c|c|c|c|}
\hline Classification & Characteristics & Examples & References \\
\hline \multicolumn{4}{|l|}{ Raw sausages } \\
\hline Fresh & $\begin{array}{l}\text { Made from fresh comminuted, uncured, non-smoked } \\
\text { meats. } \\
\text { Must be refrigerated prior to heating by the consumer. }\end{array}$ & $\begin{array}{l}\text { Breakfast sausage (USA), } \\
\text { boerewors (South Africa), } \\
\text { bratwurst (Germany), } \\
\text { merguez (North Africa), } \\
\text { siskonmakkara (Finland) }\end{array}$ & {$[2,18,22]$} \\
\hline Fermented & $\begin{array}{l}\text { Made from comminuted, cured or uncured, fermented } \\
\text { and often smoked meats. Not heat-processed. }\end{array}$ & & {$[2,18]$} \\
\hline $\begin{array}{l}\text { Semidry } \\
\text { (quickly } \\
\text { fermented) }\end{array}$ & $\begin{array}{l}\text { Stuffed in medium- and large-diameter artificial casings. } \\
\text { "Tangy" flavour produced by fermentation. Length of } \\
\text { smoking } \\
\text { and fermentation depends on type but rarely exceeds a } \\
\text { few days. } \\
\text { Improved stability of stored refrigerated. }\end{array}$ & $\begin{array}{l}\text { Variety of summer sausages, } \\
\text { cervelats, mettwursts, Lebanon } \\
\text { bologna (USA) }\end{array}$ & {$[2,18,23]$} \\
\hline $\begin{array}{l}\text { Dry } \\
\text { (slowly } \\
\text { fermented) }\end{array}$ & & $\begin{array}{l}\text { Different types of salamis, droë } \\
\text { wors } \\
\text { (South Africa, not fermented) }\end{array}$ & {$[2,18,24]$} \\
\hline \multicolumn{4}{|c|}{ Heat-processed sausages } \\
\hline $\begin{array}{l}\text { Smoked } \\
\text { precooked }\end{array}$ & $\begin{array}{l}\text { Mostly comminuted, cured, non-fermented. Final } \\
\text { cooking } \\
\text { before consumption }\end{array}$ & Chinese pork sausages, kielbasa & {$[2,18,25]$} \\
\hline $\begin{array}{l}\text { Emulsion- } \\
\text { type }\end{array}$ & $\begin{array}{l}\text { Made from comminuted well-homogenized cured } \\
\text { meats, } \\
\text { fat, water and seasoning. Usually smoked, slightly } \\
\text { cooked. } \\
\text { Ready-to-eat product. }\end{array}$ & $\begin{array}{l}\text { Frankfurters, wieners, bologna, } \\
\text { mortadella }\end{array}$ & {$[2,18,26]$} \\
\hline Cooked & $\begin{array}{l}\text { Made from previously comminuted cooked fresh or } \\
\text { cured raw materials. Final cooking after stuffing. With } \\
\text { or without smoking. Ready-to-eat product. }\end{array}$ & Liver sausage, Braunschweiger & {$[2,18]$} \\
\hline
\end{tabular}




\section{Manufacturing process of sausage and its improvement}

\subsection{Manufacturing process of sausage}

In their study entitled Preparation of sausage from spent duck-an acceptability study, Bhattacharyya et al [27] have produced three types of sausages namely: viz. sausage from broiler, spent hen and spent duck meat. After adequate thawing, the meat was weighed, cut into small chunks and minced in a meat mincer $(10 \mathrm{~mm}$ plate $)$. Recipe for preparation of $1 \mathrm{~kg}$ sausage batter included: minced meat $600 \mathrm{~g}$, vegetable fat $200 \mathrm{~g}$, ice flakes $100 \mathrm{~g}$, salt $25 \mathrm{~g}$, sugar 10 $\mathrm{g}$, monosodium glutamate $0.5 \mathrm{~g}$, sodium nitrate and sodium nitrite $0.1 \mathrm{~g}$ each, condiments $45 \mathrm{~g}$, spice mix $15 \mathrm{~g}$ and wheat flour $34.3 \mathrm{~g}$. Sausage emulsion was prepared in a bowl chopper. The emulsion was stuffed into natural and artificial casings separately, using mechanical sausage-filler and linked manually and were kept at air-conditioned temperature $\left(15-18^{\circ} \mathrm{C}\right)$ for $4 \mathrm{~h}$ for uniform setting. These were smoked for $8 \mathrm{~h}$ in a smokehouse at a temperature of $68-70^{\circ} \mathrm{C}$ and then steam-cooked to a core temperature of $85^{\circ} \mathrm{C}$ followed by cold showering for $10 \mathrm{~min}$.

In Benin, industrial production of sausage is almost non-existent. However, the growing consumption of sausages in the country is prompting their import in large quantities. Unfortunately, the quality of these products is not always guaranteed. To alleviate this problem, VETAGRO SA invested in the production of cooked chicken sausage called Mori'fresh. The process used by this company incorporates several stages namely: reception, boning, preparation of melee, embossing, cooking, conditioning, sterilization, labelling and packaging.

\subsubsection{Reception}

Broilers having undergone regular veterinary care are slaughtered at a weight greater than or equal to $2 \mathrm{~kg}$. For this purpose, knives, bleaders and the feathers are used. The carcasses are kept in the cold room.

\subsubsection{Boning}

Boning involves extracting bones and cartilage. It is practiced using knives on a teflon cutting surface.

\subsubsection{Preparation of scrums}

The quantities of lean and fatty meats are weighed and then minced (cut the meats into small pieces) and mixed in the cutter with the ingredients, additives and colouring previously weighed. Temperature controls are made during this step in order to avoid temperature increases dangerous for the quality of the product: once the emulsion is obtained, the face is sent to the pusher for embossing.

\subsubsection{Embossing}

This step consists in putting the scrums in a hose to give it its characteristic shape. The pusher has a portioner which allows the scrums to be pushed in portions into the casings. Once pushed the sausages are placed in the drying cabinet at an air-conditioned temperature $\left(15-18^{\circ} \mathrm{C}\right)$ for 2 hours to take shape and then sent to the cooker.

\subsubsection{Cooking}

In these rooms with a digested atmosphere, the product is heated so that the internal microorganisms act in order to stabilize. Cooking is done for 30 minutes at $72^{\circ} \mathrm{C}$ at heart. Once this step is completed, the sausages are put in the cooling plunger (water + ice) to stop cooking.

\subsubsection{Conditioning}

Cooked sausages are put in bags of ten (10) units. Then put in the wrapper which allows to expel the vacuum and to seal the bag.

\subsubsection{Sterilization}

The packaged sausages are placed in the sterilizer at $100^{\circ} \mathrm{C}$ for 5 minutes.

\subsubsection{Labeling and cardboarding}

Sterilized products are labeled and cardboarded with thirty (30) bags. The cartons are stored in the cold room $\left(-18^{\circ} \mathrm{C}\right)$. 


\subsection{Improvement of manufacturing process of sausage}

Several studies have investigated the use of natural products as bio conservatives for sausages. The efficacy of nisin at three different concentrations, $12.5,25$ and $50 \mathrm{ppm}$, on the keeping quality of fish sausage in synthetic casing at ambient $\left(28 \pm 2{ }^{\circ} \mathrm{C}\right)$ and refrigerated $\left(6 \pm 2{ }^{\circ} \mathrm{C}\right)$ temperatures was assessed. Result showed that fish sausage treated with $50 \mathrm{ppm}$ of nisin was acceptable after storage at ambient temperature for 20-22 days compared with the control, which were acceptable only for 2 days [28]. The effect of lacticin 3147 and nisin on the shelf life of fresh pork sausage and their ability to control pathogens as Clostridium perfringens DSM 756, Salmonella kentucky AT1 and nonpathogenic as Listeria innocua DPC 1770. There was no significant difference in the activity of nisin and lacticin 3147 against any of the target strains used, both bacteriocins performing significantly better than sodium metabisulfite against gram-positive strains in broth systems [29].

Other authors have suggested the use of starters to improve the fermentation process. For example, Hüfner et al [30] demonstrated that the performance of Lactobacillus sakei in sausage fermentation can be improved by preinoculation treatments with sublethal heat, cold, and salt stress. In addition, the instrumental and sensory analyzes carried out by Jridi et al [31] showed that the reduction in the salt content did not depreciate the quality and acceptability of the sausages. Furthermore, the sensory evaluation demonstrated that the products made from purebred Al pigs have the highest overall appreciation values. Microbial and animal-derived natural compounds were investigated for their antimicrobial and antioxidant in fresh sausages. Table 2 summarizes the main innovations in the manufacturing process of sausage.

Table 2 Summary of the main suggested improvements in sausage processing

\begin{tabular}{|c|c|c|}
\hline $\begin{array}{l}\text { Types of sausage } \\
\text { investigated }\end{array}$ & Suggested improvement & References \\
\hline Fish sausage & Use of nisin as a preservative & [28] \\
\hline Pork Sausage & Use of Lacticin as Biopreservative & [29] \\
\hline Raw Sausage & $\begin{array}{l}\text { Improvement of Fermentation by Stress-Conditioning of the Starter Organism } \\
\text { Lactobacillus sakei }\end{array}$ & [30] \\
\hline Meat sausage & $\begin{array}{l}\text { Improvement of the physicochemical, textural and } \\
\text { sensory sausage properties by edible cuttlefish gelatin addition }\end{array}$ & [31] \\
\hline Fresh Sausage & $\begin{array}{l}\text { Shelf-life extension and improvement of the Microbiological Quality by } \\
\text { Irradiation }\end{array}$ & [32] \\
\hline Pork Sausage & $\begin{array}{l}\text { Storage Properties Improvement and Reducing of Sodium Nitrate by } \\
\text { Glycyrrhiza uralensis and Curcula longa }\end{array}$ & [33] \\
\hline - & Selection and improvement of lactic acid bacteria used in sausage fermentation & [34] \\
\hline Chicken Sausage & Use of Monoxide Hemoglobin in sausage color improvement & [35] \\
\hline Model sausage & Use of chicken sarcoplasmic proteins for rheological improvement & [36] \\
\hline $\begin{array}{l}\text { Fermented } \\
\text { Sausage }\end{array}$ & $\begin{array}{l}\text { Antioxidant Activities of Lactic Acid Bacteria for } \\
\text { Quality Improvement }\end{array}$ & [37] \\
\hline $\begin{array}{l}\text { Traditional } \\
\text { sausages }\end{array}$ & $\begin{array}{l}\text { Demonstration of the acute toxicity of the dye (Rhodamine B) used in the } \\
\text { manufacture }\end{array}$ & [38] \\
\hline
\end{tabular}

\section{Essential oils}

\subsection{Definition and localization}

Essential oil is a product obtained from a vegetable raw material, either by steam entrainment, or by mechanical processes from the Citrus epicarp or by dry distillation, and which is separated from the aqueous phase by physical processes [39]. 
Essential oils are produced in specialized glandular cells covered with a cuticle. They are then stored in cells with essential oils (Lauraceae or Zingiberaceae), in secretory hairs (Lamiaceae), in secretory bags (Myrtaceae or Rutaceae) or in secretory channels (Apiacieae or Asteraceae). They can also be transported into the intracellular space when the gasoline pockets are located in the internal tissues [40]. They are located either in the flowers (ylang-ylang, bergamot, rose), or in the flowering tops (marigold, lavender), or in the leaves (lemongrass, eucalyptus), or in the bark (cinnamon), or in roots (vetiver), or in fruits (vanilla), or in seeds (nutmeg) or elsewhere in the plant [41].

\subsection{Essential oils and food}

There are several reasons for using essential oils to improve the quality and preservation of food. These plant extracts, reservoirs of natural antioxidants, contain molecules with interesting biological activities and have no major effects on the environment and human health [42, 43, 44]., Néguefack et al. [45] reported the fungicidal effect of the essential oils of Cymbopogon citratus on the toxinogenic molds found in certain foods. More recently, other authors have reported the effectiveness of plant extracts for the conservation of tomatoes [46], Peuhl "waragashi" cheese [47], peanuts [48], fish [49], margarine [50] and meat [51], local beer tchakpalo [52] and and lanhouin-based cube broth [53].

\subsection{Mechanisms of antimicrobial action of essential oils}

The antimicrobial mechanisms of plant extracts action have been widely relayed by several publications. Essential oils kill the fungal cell via binding primarily to ergosterol, the major sterol found in fungal cellular membrane. This binding destroys the osmotic integrity of the membrane, and this is followed by leakage of intracellular potassium, magnesium, sugars, and metabolites and finally by cellular death. Lipid characteristics of essential oils act via the same mechanism. It has been suggested that oxidative damage due to essential oil may also contribute to its antifungal activity against Candida $[42,45]$.

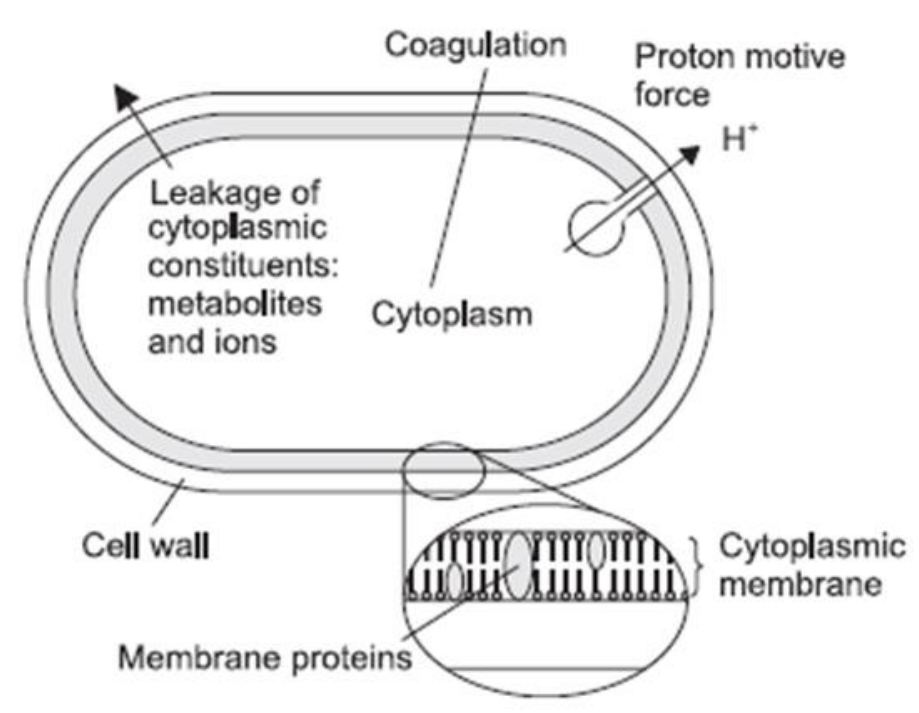

Figure 1 Locations and mechanisms in the bacterial cell thought to be sites of action for essential oils components [42].

Considering the large number of different groups of chemical compounds present in essential oils, it is most likely that their antibacterial activity is not attributable to one specific mechanism but that there are several targets in the cell. An important characteristic of essential oils and their components is their hydrophobicity, which enables them to partition in the lipids of the bacterial cell membrane and mitochondria, disturbing the structures and rendering them more permeable. Leakage of ions and other cell contents can then occur [42, 54]. Figure 1 presented the locations in the bacterial cell thought to be sites of action for essential oils components. Major effects are: degradation of the cell wall, damage to cytoplasmic membrane, damage to membrane proteins, leakage of cell contents, coagulation of cytoplasm and depletion of the proton motive force $[42,54,55]$.

Otherwise the use of volatile plant extracts to improve the quality of various forms of sausage has been proposed by several studies (table 3). 
Table 3 Effectiveness of essential oils in sausages

\begin{tabular}{|c|c|c|c|}
\hline $\begin{array}{l}\text { Essential oils } \\
\text { from }\end{array}$ & $\begin{array}{l}\text { Highlighted } \\
\text { potentials }\end{array}$ & Key findings & References \\
\hline $\begin{array}{l}\text { Myristica } \\
\text { fragrans }\end{array}$ & $\begin{array}{l}\text { Oxidative and } \\
\text { Microbial } \\
\text { stability }\end{array}$ & $\begin{array}{l}\text { Addition of nutmeg essential oil influenced the slower lipid } \\
\text { oxidation and growth of total aerobic mesophilic bacteria, as well as } \\
\text { improvement of aroma of cooked sausages during long storage } \\
\text { period ( } 60 \text { days) }\end{array}$ & [56] \\
\hline $\begin{array}{l}\text { Juniperus } \\
\text { communis L. }\end{array}$ & $\begin{array}{l}\text { Antioxidant } \\
\text { Activity }\end{array}$ & $\begin{array}{l}\text { Essential oil, used in a concentration of } 0.01 \mu \mathrm{l} / \mathrm{g}(\mathrm{JO} 1) \text {, retarded } \\
\text { radical formation and reduced the growth of total aerobic } \\
\text { mesophilic bacteria and improved the colour of cooked sausages, } \\
\text { with slight to moderate alteration of the original flavour of cooked } \\
\text { sausages. }\end{array}$ & {$[57]$} \\
\hline $\begin{array}{l}\text { Origanum } \\
\text { vulgare }\end{array}$ & $\begin{array}{l}\text { Antifungal } \\
\text { activity, influence } \\
\text { on Microbial and } \\
\text { Physicochemical } \\
\text { Characteristics }\end{array}$ & $\begin{array}{l}\text { Presence of some molds on the surface of fermented sausages can be } \\
\text { reduced by the use of OEO without causing considerable } \\
\text { modifications to the physicochemical and microbiological } \\
\text { properties of the sausages. }\end{array}$ & [58] \\
\hline $\begin{array}{l}\text { Origanum } \\
\text { majorana } L\end{array}$ & $\begin{array}{l}\text { Antimicrobial } \\
\text { activity }\end{array}$ & $\begin{array}{l}\text { Addition of essential oil to fresh sausage exerted a bacteriostatic } \\
\text { effect at oil concentrations lower than the MIC, while a bactericidal } \\
\text { effect was observed at higher oil concentrations which also caused } \\
\text { alterations in the taste of the product. }\end{array}$ & [59] \\
\hline $\begin{array}{l}\text { Satureja } \\
\text { montana L. }\end{array}$ & $\begin{array}{l}\text { Antioxidant } \\
\text { effects }\end{array}$ & $\begin{array}{l}\text { The use of savory essential oils in high concentrations with high } \\
\text { levels of sodium nitrite can promote undesirable sensory changes by } \\
\text { changing the characteristic color of the product. The antioxidant } \\
\text { activity and effect of essential oils on lipid oxidation in mortadella } \\
\text { was confirmed by reduced oxidative reactions. }\end{array}$ & {$[60]$} \\
\hline Laurus nobilis & $\begin{array}{l}\text { Antibacterial } \\
\text { activity }\end{array}$ & $\begin{array}{l}\text { Application of essential oils in fresh sausages at the concentrations } \\
\text { of } 0.05 \text { and } 0.1 \mathrm{~g} / 100 \mathrm{~g} \text { might provide additional protection of this } \\
\text { product against microbial growth, thereby increasing its shelf life. }\end{array}$ & {$[61]$} \\
\hline $\begin{array}{l}\text { Ocimum } \\
\text { basilicum L. }\end{array}$ & $\begin{array}{l}\text { Antibacterial } \\
\text { activity }\end{array}$ & $\begin{array}{l}\text { Basil essential oil presented antibacterial activity in all tested } \\
\text { bacteria, with the exception of Pseudomonas aeruginosa. }\end{array}$ & [62] \\
\hline $\begin{array}{l}\text { Mentha } \\
\text { piperita }\end{array}$ & $\begin{array}{l}\text { Functional } \\
\text { property }\end{array}$ & $\begin{array}{l}\text { Replacement of } 50 \% \text { of nitrite with essential oils is a reasonable } \\
\text { approach in order to put down harmful effects of nitrite in sausage } \\
\text { and to enhance functionality of the product. }\end{array}$ & [63] \\
\hline $\begin{array}{l}\text { Citrus waste } \\
\text { water, thyme } \\
\text { and oregano } \\
\text { essential }\end{array}$ & & $\begin{array}{l}\text { Addition of essential oil to cooked meat products is a viable } \\
\text { alternative for increasing the oxidative stability of the samples, } \\
\text { while reducing nitrite levels. }\end{array}$ & [64] \\
\hline
\end{tabular}

\section{Legislation}

A certain number of molecules making up essential oils have been registered by the European Commission for their use as flavorings in foodstuffs. Registered flavors are considered to pose no risk to the health of the consumer and include, among others, carvacrol, carvone, cinnamaldehyde, citral, p-cymene, eugenol, limonene, menthol and thymol [42, 65]. Estragole and methyl eugenol were removed from the list in 2001 due to their side effects. The United States, through the United States Food and Drug Administration (USFDA) has classified these substances as Generally Recognized as Safe Food Additives (GRAS). However, Astragola, expressly prohibited as a flavoring in the European Union, is authorized on the USFDA list [42].

New flavors can only be registered after toxicological and metabolic studies according to the Regulatory Commission (EC) $n^{\circ} 622 / 2002$, which could involve a considerable financial effort. If these molecules are added to food for purposes other than flavoring, these molecules can be considered as new food additives. Thus, obtaining approval as a safe food additive would involve significant metabolic and toxicological studies, the cost of which can be prohibitive. Therefore, 
it would be interesting, especially for developing countries, to use a spice or an essential oil as a food ingredient, than to use molecules which will require prior authorizations (Smid and Gorris, 1999).

\section{Conclusion}

In order to improve sausage production technology and limit the use of chemicals, several alternatives have been proposed in the literature. In review, we highlighted most of these innovations. Regarding the improvement in processing, the use of nisin, acticin as biopreservative, use of starter to improve fermentation, physicochemical, textural and sensory properties of sausage, shelf-life extension by irradiation, storage properties improvement and reducing of Sodium Nitrate by Glycyrrhiza uralensis and Curcula longa... have been suggested. In addition, plant extracts are used for their antioxidant, antimicrobial and functional properties.

\section{Compliance with ethical standards}

\section{Acknowledgments}

The authors thank VETAGRO SA for their financial support.

\section{Disclosure of conflict of interest}

The authors agree no conflict of interest.

\section{References}

[1] Ministère de l'économie des finances et de l'industrie direction des affaires juridiques groupe permanent d'étude des marches de denrées alimentaires (GPEM/DA). Guide de présentation des charcuteries N B2-17-99.

[2] Hugo CJ and Hugo A. (2015). Current trends in natural preservatives for fresh sausage products. Trends in Food Science \& Technology, 45(1), 12-23.

[3] Lobo IB. (2010). Analyse bacteriologique des saucissons vendus dans les alimentations de la ville de kisangani dans la commune makiso. Departement des sciences biotechnologiques.

[4] Margerin J. (2014). Maîtrise de la qualité microbiologique de saucisses fraîches à teneur réduite en nitrite par biopréservation (Doctoral dissertation, Université de Lorraine).

[5] Six SC, Buyser M, Vignaud, M, Dao TT, Messio S and Payraud S. (2012). Toxi-infections alimentaires collectives à Bacillus cereus: bilan de la caractérisation des souches de 2006 à 2010. Bull. Épidémiol. Anim. Aliment, 50, 5761.

[6] Oumokhtar B, Karib H, Bouchriti N and Araba A. (1998). Appréciation de la qualité bactériologique de la viande et des abats de taurillons fraîchement abattu dans les abattoirs de Rabat. Revue Marocaine des Sciences Agronomiques et Vétérinaires, 18(3), 169-176.

[7] Romans JR, William JC Carloson CW, Greaser ML and Jones KW. (2001). The meat we eat (4th ed.). Danville: Interstate Publishers, Inc.

[8] Kim SJ, Cho, AR and Han J. (2013). Antioxidant and antimicrobial activities of leafy green vegetable extracts and their application to meat product preservation. Food Control, 29, 112-120.

[9] Jatto WO and Adegoke GO. (2010). Storage studies on cashew juice preserved with water extracted Aframomum danielli Electr. J. Environ. Agric. Food Chem, 9, 1351-1359.

[10] Sessou P, Souaïbou F, Paulin A, Issaka Y and Dominique S. (2012). In vitro Antifungal activities of Essential oils extracted from Fresh Leaves of Cinnamomum zeylanicum and Ocimum gratissimum against Foodborne pathogens for their use as Traditional Cheese Wagashi conservatives. Research Journal of Recent Sciences, 1(9), 67-73.

[11] Konfo C, Ahoussi-Dahouénon E, Sessou P, Yehouenou B, Djenontin S, De Souza, C and Sohounhloué D. (2012). Stabilization of local drink" Tchakpalo" produced in Benin by addition of essential oil extracted from fresh leaves of Cymbopogon citratus. International Research Journal of Biological Sciences, 1(8), 40-49. 
[12] Konfo CT, Chabi NW, Agbadjizo J, Dahouenon-Ahoussi E, Soumanou MM and Sohounhloue DC. (2014). Influence de la feuille de Hemizygia bracteosa (Benth) sur la qualité de la bière du sorgho" tchakpalo" produite au Bénin. International Journal of Innovation and Applied Studies, 7(2), 453-463.

[13] Konfo CTR, Chabi NW, Dahouenon-Ahoussi E, Cakpo-Chichi M, Soumanou MM and Sohounhloue DCK. (2020). Improvement of African traditional sorghum beers quality and potential applications of plants extracts for their stabilization: a review. Journal of Microbiology, Biotechnology and Food Sciences, 9(4), 190-196.

[14] Kpatinvoh B, Adjou ES, Dahouenon-Ahoussi E, Konfo, TC, Atrevi B., Soumanou MM and Sohounhloue DC. (2017). Efficacité des huiles essentielles de trois plantes aromatiques contre la mycoflore d'altération du niébé (Vigna unguiculata L., Walp) collecté dans les magasins de vente du Sud-Bénin. Journal of Applied Biosciences, 109(1), 10680-10687.

[15] Zannou A, Konfo CTR, Gbaguidi MAN and Ahoussi-Dahouenon E. Antimicrobial activity of extracts from Cymbopogon citratus L. and of Mentha spicata L. against fungal and bacterial strains isolated from peuhl's cheese (Waragashi) produced in Benin. International Journal of Advanced Research, 3(10), 1684-1695.

[16] Allagbé AC, Degnon RG, Konfo CTR, Kpatinvoh B and Farid BM. (2020). Improvement of smoked and fermented dried fish processing and application of essential oils as their natural preservatives. World Journal of Advanced Research and Reviews, 06(02), 129-138.

[17] Définitions lexicographiques [archive] et étymologiques [archive] de "saucisse » du Trésor de la langue française informatisé, sur le site du Centre national de ressources textuelles et lexicales [consulté le 09 Juin 2020].

[18] Savic IV. (1985). Small-scale sausage production. Rome, Italy: Publications Division, Food and Agriculture Organization of the United Nations.

[19] Harper D. (2014). The online etymology dictionary.

[20] Tanikawa E. (1963). Fish sausage and ham industry in Japan. In Advances in food research, 12, 367-424.

[21] Rust RE. (1987). Sausage products. In J. F. Price, \& B. S. Schweigert (Eds.), The science of meat and meat products (3rd ed.). (pp. 457e486). Westport: Connecticut, USA: Food \& Nutrition Press, Inc.

[22] Cocolin L, Rantsiou K, Iacumin L, Urso R, Cantoni C and Comi G. (2004). Study of the ecology of fresh sausages and characterization of populations of lactic acid bacteria by molecular methods. Appl. Environ. Microbiol. 70(4), 1883-1894.

[23] Holdren WC and Alden DE. (1998). U.S. Patent No. 5,736,186. Washington, DC: U.S. Patent and Trademark Office.

[24] Sebranek JG. (2004). Semidry fermented sausages. Food Science and Technology-New York-marcel dekker-, 385396.

[25] Li R, Carpenter JA and Cheney R. (1998). Sensory and instrumental properties of smoked sausage made with mechanically separated poultry (MSP) meat and wheat protein. Journal of Food Science, 63(5), 923-929.

[26] Choi YS, Jeong JY, Choi, JH, Han DJ, Kim HY, Lee MA and Kim CJ. (2008). Effects of dietary fiber from rice bran on the quality characteristics of emulsion-type sausages. Food Science of Animal Resources, 28(1), 14-20.

[27] Bhattacharyya D, Sinhamahapatra M and Biswas S. (2007). Preparation of sausage from spent duck-an acceptability study. International journal of food science \& technology, 42(1), 24-29.

[28] Scannell AG, Ross RP, Hill C and Arendt EK. (2000). An effective lacticin biopreservative in fresh pork sausage. Journal of food protection, 63(3), 370-375.

[29] Raju CV, Shamasundar BA and Udupa KS. (2003). The use of nisin as a preservative in fish sausage stored at ambient $\left(28 \pm 2{ }^{\circ} \mathrm{C}\right)$ and refrigerated $\left(6 \pm 2{ }^{\circ} \mathrm{C}\right)$ temperatures. International journal of food science \& technology, $38(2), 171-185$.

[30] Hüfner E and Hertel C. (2008). Improvement of raw sausage fermentation by stress-conditioning of the starter organism Lactobacillus sakei. Current microbiology, 57(5), 490-496.

[31] Jridi M, Abdelhedi O, Souissi N, Kammoun M, Nasri M and Ayadi MA. (2015). Improvement of the physicochemical, textural and sensory properties of meat sausage by edible cuttlefish gelatin addition. Food bioscience, $12,67-72$.

[32] Hammad A AI, El-Mongy TM and Mabrouk AK. (2000). Shelf-life extension and improvement of the microbiological quality of fresh sausage by irradiation. Egyptian Journal of Radiation Sciences and Applications, 13(1), 59-75. 
[33] Cho SH, Jung SA, Song E J, Lee SY, Kim KBWR, Park JG and Ahn DH. (2006). Effect of improvement of storage properties and reducing of sodium nitrate by Glycyrrhiza uralensis and Curcula longa in pork sausage. Journal of the Korean Society of Food Science and Nutrition, 35(8), 997-1004.

[34] Hammes WP and Hertel C. (1996). Selection and improvement of lactic acid bacteria used in meat and sausage fermentation. Le Lait, 76(1-2), 159-168.

[35] Xu P, Zhu X, Tan S, Qin H and Zhou C. (2016). The role of monoxide hemoglobin in color improvement of chicken sausage. Food science and biotechnology, 25(2), 409-414.

[36] Miyaguchi Y, Sakamoto T, Hayashi Y and Nagayama K. (2005). Effective use of culled hens: the use of chicken sarcoplasmic proteins for rheological improvement of model sausage. Journal of the Japanese Society for Food Science and Technology (Japan).

[37] Zhang Y, Hu P, Lou L, Zhan J, Fan M, Li D and Liao Q. (2017). Antioxidant activities of lactic acid bacteria for quality improvement of fermented sausage. Journal of food science, 82(12), 2960-2967.

[38] El Allaoui A, Rhazi Filali F, Oumokhtar B and Ibijbijen J. (2011). Evaluation de la toxicité aigue du colorant (Rhodamine B) utilisé dans la fabrication des saucisses traditionnelles dans la ville de Meknès au Maroc. Science Lib, 3(5).

[39] NF EN ISO 9235. (2014). T75-006. Matières premières aromatiques naturelles - Vocabulaire - Matières premières aromatiques d'origine naturelle.

[40] Bruneton J. (1999). Pharmacognosie-Phytochimie-Plantes médicinales. 3è édition technique \& documentation. 1120.

[41] Anton R and Lobstein A. (2005). Plantes aromatiques. Epices, aromates, condiments et huiles essentielles. Tec

[42] Burt S. (2004). Essential oils: their antibacterial properties and potential applications in foods-a review. International journal of food microbiology, 94(3), 223-253.

[43] Tatsadjieu NL, Dongmo PJ, Ngassoum MB, Etoa FX and Mbofung, CMF. (2009). Investigations on the essential oil of Lippia rugosa from Cameroon for its potential use as antifungal agent against Aspergillus flavus Link ex. Fries. Food control, 20(2), 161-166.

[44] Yehouenou B, Wotto V, Bankole H, Sessou P, Noudogbessi JP and Sohounhloue D. (2010). Chemical study and antimicrobial activities of volatile extracts from fresh leaves of Crassocephalum rubens (juss \& jack) s. moore against food-borne pathogens. Scientific Study \& Research: Chemistry \& Chemical Engineering, Biotechnology, Food Industry, 11(3), 341-349.

[45] Nguefack J, Dongmo JL, Dakole CD, Leth V, Vismer HF, Torp J, Guemdjoma, Mbeffoa M, Tamguea O, Fotioa D, Amvam Zollo PH and Nkengfack AE. (2009). Food preservative potential of essential oils and fractions from Cymbopogon citratus, Ocimum gratissimum and Thymus vulgaris against mycotoxigenic fungi. International Journal of Food Microbiology, 131(2), 151-156.

[46] Houinsou RDL, Ahoussi E, Sessou P, Yèhouénou B and Sohounhloué D. (2012). Antimicrobial activities of essential oil extracted from leaves of ocimum gratissimum L. against pathogenic and adulterated microorganisms associated to tomato in Bénin. International Journal of Biosciences (IJB), 2(11), 90-100.

[47] Sessou P, Farougou S, Kaneho S, Djenontin S, Alitonou GA, Azokpota P, Youssao I and Sohounhloué D. (2012). Bioefficacy of Cymbopogon citratus essential oil against foodborne pathogens in culture medium and in traditional cheese wagashi produced in Bénin. International Research Journal of Microbiology, 3(12), $406-415$.

[48] Adjou ES and Soumanou MM. (2013). Efficacité des extraits de plantes dans la lutte contre les moisissures toxinogènes isolées de l'arachide en post-récolte au Bénin. Journal of Applied Biosciences, 70 (1), 5555-5566.

[49] Degnon RG, Agossou VE, Adjou ES, Dahouenon-Ahoussi E, Soumanou MM and Sohounhloue DC. (2013). Évaluation de la qualité microbiologique du chinchard (Trachurus trachurus) au cours du processus de fumage traditionnel. Journal of Applied Biosciences, 67, 5210-5218.

[50] Himed L and Barkat M. (2014). Élaboration d'une nouvelle margarine additionnée des huiles essentielles de Citrus limon. OCL, 21(1), A102.

[51] Siewe FB, Mbougueng PD, Tatsadjieu LN, Noumo TN and Mbofung CM. (2015). The Potential Application of Syzygium aromaticum and Cymbopogon citratus Essential Oils as Natural Preservatives of Beef Patties. Food and Nutrition Sciences, 6(03), 374. 
[52] Konfo CTR, Chabi NW, Dahouenon-Ahoussi E, Cakpo-Chichi M, Soumanou MM and Sohounhloue DCK. (2020). Improvement of African traditional sorghum beers quality and potential applications of plants extracts for their stabilization: a review. Journal of Microbiology, Biotechnology and Food Sciences, 9(4), 190-196.

[53] Allagbé AC, Degnon RG and Konfo CTR. (2020). Development, physico-chemical and microbiological characterization of a cube broth based on lanhouin stabilized using plant extracts. International Journal of Advanced Research, 8(04), 299-306.

[54] Ultee A, Bennik MHJ and Moezelaar RJAEM. (2002).The phenolic hydroxyl group of carvacrol is essential for action against the food-borne pathogen Bacillus cereus. Appl. Environ. Microbiol, 68(4), 1561-1568.

[55] Lambert RJW, Skandamis PN, Coote PJ and Nychas GJ. (2001). A study of the minimum inhibitory concentration and mode of action of oregano essential oil, thymol and carvacrol. Journal of applied microbiology, 91(3), 453462.

[56] Šojić B, Tomović V, Kocić-Tanackov S, Škaljac S, Ikonić P, Džinić N and Kravić S. (2015). Effect of nutmeg (Myristica fragrans) essential oil on the oxidative and microbial stability of cooked sausage during refrigerated storage. Food Control, 54, 282-286.

[57] Šojić B, Tomović V, Jokanović M, Ikonić P, Džinić N, Kocić-Tanackov S and Šojić N Ž. (2017). Antioxidant activity of Juniperus communis L. essential oil in cooked pork sausages. Czech Journal of Food Sciences, 35(3), 189-193.

[58] Chaves-lópez C, Martin-SAacute, Nchez AM, Fuentes-Zaragoza E, Viuda-Martos M, Fernandez-Lopez J, Sendra E and Alvarez JAP. (2012). Role of Oregano (Origanum vulgare) essential oil as a surface fungus inhibitor on fermented sausages: evaluation of its effect on microbial and physicochemical characteristics. Journal of food protection, 75(1), 104-111.

[59] Busatta C, Vidal RS, Popiolski AS, Mossi AJ, Dariva C, Rodrigues, MRA and Cansian RL. (2008). Application of Origanum majorana L. essential oil as an antimicrobial agent in sausage. Food microbiology, 25(1), $207-211$.

[60] De Oliveira TL C, De Carvalho SM, De Araújo Soares R, Andrade MA, Das Graças Cardoso M, Ramos EM and Piccoli RH. (2012). Antioxidant effects of Satureja montana L. essential oil on TBARS and color of mortadella-type sausages formulated with different levels of sodium nitrite. LWT-Food Science and Technology, 45(2), 204-212.

[61] Da Silveira SM, Luciano, FB, Fronza N, Cunha Jr, A, Scheuermann GN and Vieira CRW. (2014). Chemical composition and antibacterial activity of Laurus nobilis essential oil towards foodborne pathogens and its application in fresh Tuscan sausage stored at 7 C. LWT-Food Science and Technology, 59(1), 86-93.

[62] Gaio I, Saggiorato AG, Treichel H, Cichoski AJ, Astolfi V, Cardoso RI and Cansian RL. (2015). Antibacterial activity of basil essential oil (Ocimum basilicum L.) in Italian-type sausage. Journal für Verbraucherschutz und Lebensmittelsicherheit, 10(4), 323-329.

[63] Moarefian M, Barzegar M, Sattari M and Naghdi Badi H. (2012). Production of functional cooked sausage by Mentha piperita essential oil as a natural antioxidant and antimicrobial material. Journal of Medicinal Plants, 1(41), 46-57.

[64] Viuda-Martos M, Ruiz-Navajas Y, Fernández-López J and Pérez-Álvarez JA. (2009). Effect of adding citrus waste water, thyme and oregano essential oil on the chemical, physical and sensory characteristics of a bologna sausage. Innovative Food Science \& Emerging Technologies, 10(4), 655-660.

[65] Konfo, CTR. (2016). Pratiques endogènes de production et efficacité d'extraits de plantes aromatiques dans la stabilisation du " tchakpalo ", une bière de sorgho, au Bénin. Thèse de doctorat de l'Universite D'Abomey-Calavi. Option : Science des Aliments. Spécialité : Microbiologie et Biotechnologie Alimentaire, 199.

\section{How to cite this article}

Gbaguidi MD, Degnon René G, Konfo Tétédé RC, Kpatinvoh B and Baba-Moussa F. (2020). Improvement in sausage manufacturing process and potential use of selected aromatic plants as their bio preservatives in Benin. GSC Biological and Pharmaceutical Sciences, 11(03), 166-176. 